\title{
Environmental consequences of tidal power in a hypertidal muddy regime : the Severn estuary (UK)
}

\author{
par R. Kirby
}

Ravensrodd Consultants Ltd.

\section{INTRODLCTION}

The pre-batrage Rance estuary had a tidal range not dissimilar to the Severn, both being categorised as hypertidal (Mean Tidal Range $>6.0 \mathrm{~m}$ ). The Mean Tidal Range of the Severn is actually $8.55 \mathrm{~m}$. Although their tidal ranges were comparable, in other respects they were physically diswimilar, notably in the fact that the Rance was and remains a sandy dominated system, whereas the Severn, especially along its coast, is predominantly muddy. The combination of the hypertidal regime and the muddiness of the system, coupled to a degrec with its exposure to westcrly waves, lead to the sedimentary regime controlling and dominating almose all aspects of the ecosystems of the Severn. Indeed, there can be few sites in the world quite so dominated by their sedimentary system as the Severn.
Should a tidal power barrage ever be constructed in the estuary, as has been investigated over a 20 year period from 1973-1993 to pre-feasibility level, it would reduce the tidat range withir its basin to macrotidal $(4.0-6.0 \mathrm{~m})$ as well as reducing the wave climate in much of the csttary. The ecosystem would change in a major way as at result, the cxtreme degree of physical control would diminish and within the basin the water, subtidal and intertidal environments would become more closely comparable with "nomal" macrotidat muddy faunal and floral ecosystems. Outside the barrage a hypertidal sediment-dominated ccosystem would persist in Bridgwater Bay. The paper concentrates on describing the essential character of the present physical and biological systems and uses these as a platform to anticipate physical and biological changes arising from a Cardifi-Weston barrage.

Conséquences enyironnementales de l'énergie marémotrice en régime de grandes marées boueuses: l'estuaire de la Severn

Les régimes à narées de grande amplitude, conme dans l'estiaire de la Severn, posent des difficultés a la faune et à la flore en raison des fluctuations énergétiques semi-diumes et semi-lunaires. En particulier au printemps, la forte concentration en sédiments enpêche la photosynthèse et les niveatix de phutoplanctons sont au plus bas. En marếe de morte eau, les sédiments se déposent et une faune de lit composée d'individus immatures se développe.

Les conditions de vie dans la zone intercotidale sont également difficiles en raison de l'érosion pendant les tempêtes. On y trouve des depôts de coquillages qui s'atturäent:

L'installation d'un barage entrânerait une baisse de la turbidité et un accơissement de la photosynthèse et du phytoplanctori, stimtlant la chathe alimentaire. L'écosystème estuarien devrait se développer Des études ont montré que la Severn possède actuellement un régime atypique en ce qui concerne lës sédiments. La fermeture de l'estuaire permettrait aux oiseaux de trouver de la nourriture et les atirenait Même si ca parait bizarre en labserice de barrage, si l'on épure les eaux usées, on ne trourera plus d'oiseaux. 


\section{DEDIMENTARY REGIME OF THE ESTLARY}

The sedimentary regime has a number of features specific to an exposed, hypentidal estuary. During the last 10,000 years, the recovery phase from the latest glacial advance, the Severn and Bristol Channel has been supplied with gravel. sard and mud from its hinteriand, from glaciers and their associnted products. Visually and superficially the estuary gives the impression of being superabundantly supplied, especially with fine- grained sediment. Examination of maps of unconsolidated sediment distribution and thickness in fact confirms the contrary, much of the bed of the Bristol Channel and Severn Estuary is bare rock or has only timited veneers of unconsolidated sediment (fig. l). The best way of explaining this apparent contridiction is by saying that the Severn, in relative terms, has much less unconsolidated sediment contained within it than any other UK estuary, but that a disproportionately high fraction of this is mobile at any one place and time.

Another manifestation of the high energy of the system is that the various grain sizes of sediment are fractionated one from the other to an unusual and extreme degree. Thus, although interbedded pure sands, pure silst and pure clays occur in some places, many aress tte chatuaterised by very well sorted sediments of a single and narrow grain- size spectrum. Sand size decreases systematically from the outer to the inner estuary [1] testifying to a net up-estuary sand urnsport arising from ebb-hood asymmetry and sea level rise. Mixed substrates, almost universally to be found in micro, meso and macrotidal systems, are rarely encountered in the Severn. This extreme fractionation into individual grain-size components is perpetuated and exaggerated by the almost total absence of colonising organisms. As a resut the primary sedimentary fabric of deposits in core samples, representing many dccades of deposition, is preserved witnout the bioturbation and the secondary fabric generation catrsed by animals, which is so universal almost everywhere else [2]. This fractionation and sparsity of organisms feeds back to the lora and laura. with the consequence that impoverished muddy and sandy faunds oceur but mixed muddy sand and sandy mulf faunas tend to be absent.

The fauna and flowa is very largely cominated by the mobility and instability of all grades of sediment, although it is the line cohesive component which is especially problematicat. The intertidal and subtidat bed, as well as the water coltumn itself, is involved. Taking these in tum :

\subsection{Intertidal zone}

Arising from the combined effects of sea defence construction commencing 1000 years ago and compounded by sea level rise, the intertidal mudhats have a low and concave cross-sectional profile [3] and are experiencing steady erosion [4]. Where long-term rate of chunge can be estimated. any remaining salt marshes are recreating laterally at rales reaching several metres/year and at the same time the mud flats are eroding vertically, preserving their concave equilibrium shape. The rate of vertical erosion lies in the region $3.0 \mathrm{~m} / 70$ years [4]. Wany tidal flats have extensive arcas of overconsolidated Holocene clays and peats, although they are veneered at times and in places by unconsolidated mud layers, which are largely the product of the self-destruction of the intertidal zone. Erosion-dominated medshores with these general characteristics are well known trom around the world. What is notably different in the Severn is that elsewere, winnowing of tidal tlat muds by waves leads to the accumulation and up-shore migration of large banks of intertidally-derived shell deposits called Cheniers. Despite eroding rapidly, and certainly for the last severul hundred years, there are no cheniers either out on the tidal tlat or banked up at high water mark. This testiftes to the long term ratural inability of this hypertidal regime to provide a itost for "normal" estuarine shelly intertidal faunas. A further constraining infuence on intertidal zone colonisation is the presence

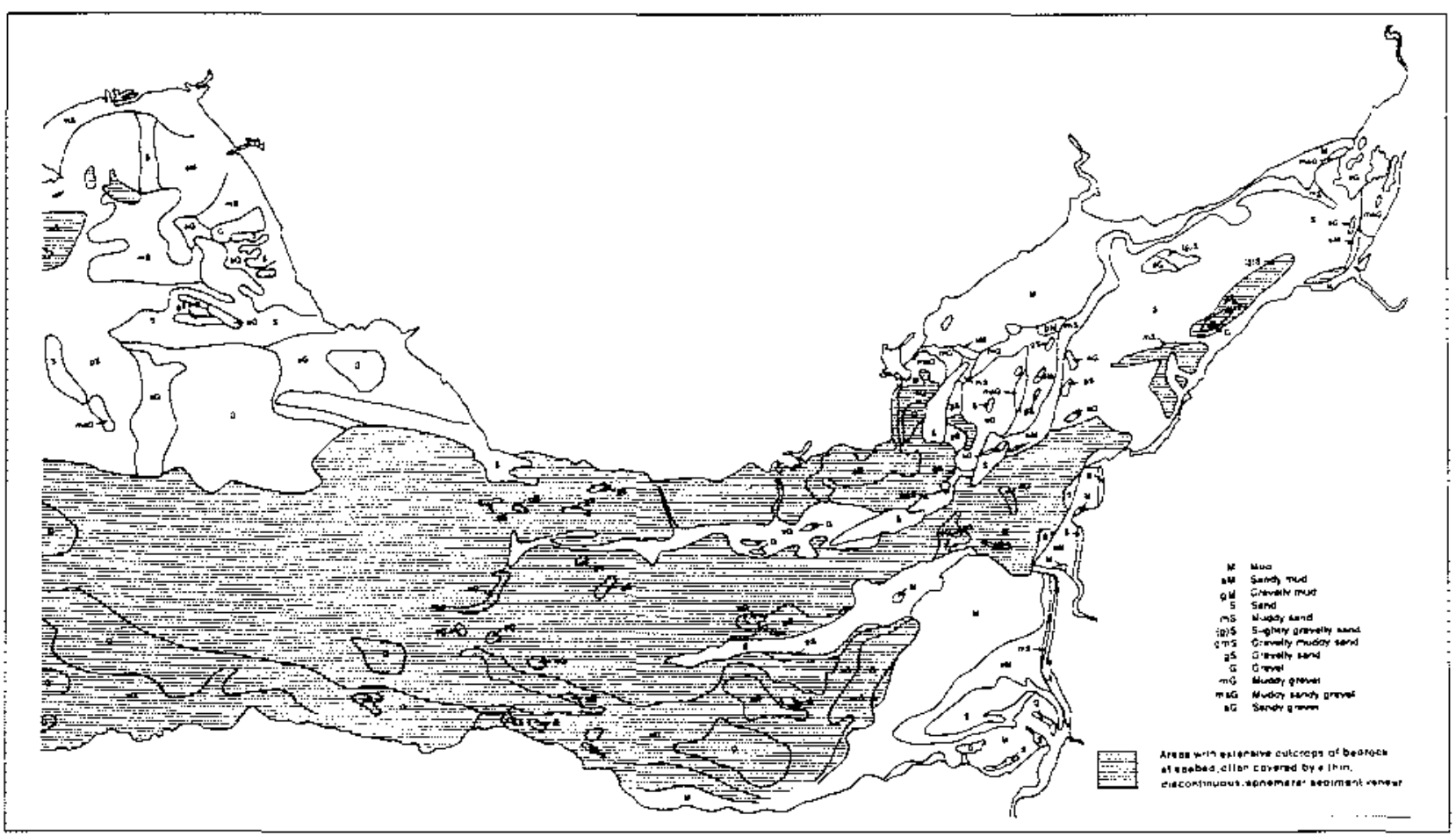

1. Distribution of rock outcrops (toned zone) at the seabed in the Severn Estuary and Bristol Channel. Note tendaney for sediment starvation to be greatest along the lower (English) coast. (Data from BGS). 
Iwice a month of extensive neaptide lluid mud layers 15 : Finally, the exposed intertidel zone is unusually susceptible to the effects of wave attack during gales. Storm waves strip the unconsolidated host sediment which provides the ephemeral habitat for intertidal invertebrate faunas ffog. $2 ;[6,7]$ generating elevated zones of suspended solids concentrations along the coast 18. AH these sedimentary factors lead to the intertidal zone being an actely difficult one for organisms to colonise.

\subsection{Subtidal zone}

Although at less stressful regime in so much as it is not susceptible to the effects of brealking waves, the subtidal zone has the drawback that it is never, or virtually never, able to receive direct sunlight due to the masking effect of the overbying high lurbidity water column. There are three major types of substrate, rock exposures which provide a slable tholdfast for colonies of the reef-building worm Sabellaria and alsu sandy and muddy deposits. Both of these are somewhat unstable, especially at the bed/water surface. and also regularly swept by bed load materials which may be abrasive. Instability, coupled with farye scale oscillation in bed clevation, make these deposits extremely diflicult to colonise, other than for the briefest period. In respect of muddy grounds and to a lesser extent sandy areas, in addition to instability of the bed, there is a further factor. On spring tides the concentration of near-bed suspended sediment may be high (often $5-10,000 \mathrm{mg}^{-1}$ ) but on neaps large quantities of sediment settle rapidly onto the bed to form neap tide fluid muds $\{5\}$. These are both extersive and frequenty occupy at least the $1.0 \mathrm{~m}$ zone of the water column immediately on top of the bed. Two teatures make them and the beds they veneer especially problematical for colonising organisms. Firstly, their concentration, often $20,000-$ $100,000 \mathrm{mg}:$ is such that they have no strength and organisms camot keep a burrow open, secondly they are anaerobic. For perhaps 2-5 days a formight such teposits form veneers over muddy and sandy subtidal bed sediments. The instability, coupled with frequent smotherim by anacrobic suspensions, is in combination cspecially stressful for organisms $\{9\}$.

\subsection{Water column}

The very shrong currents, coupled with fortnightly cycling of fine sectiment between the water column and bed, are somewhat extreme 551. On spring tides the total fine sediment load between Avonmouth and Watchet exceeds 30 milIion tonnes by an unknown amount. By the neap tide phase only 14 days bater most of this load has settled onto the bed as the ephemeral fluid mud layers and only about 4-5 million tontes remains dispersed in the overlying water column. On the entrainment phase after each neap tide settlement, anaerobic near-bed layers rise into the water column leading to a short tern natural dissolved oxygen sag. Both the high turbidities, coupled with the regular oxygen depletion, lead to problems for pelagic species.

\section{BIOLOGICAL RESPONSE OF THE ESTUARY}

As may be anticipated from understanding of the above, recruitment into the Severn from seawards is not a problem. The spring tidal excursion at the Holms istands extends to $43 \mathrm{~km}[5]$ and the area is renowned for the efficiency of vertical mixing, certainly of water if not sediment. Although initial recruitment is enormous, gaining a foothold in such a regime is extremely difficult. In some respects the area may be regarded as highly productive biologically. For example, intertidal rocks and bridge piers are extensively colonised by Fucus which is in turn regularty torn off on spring tides forming extensive floating windrows at the estuary surface and permitting fresh colonisation. Sabellaria colonics are likely to be mature if nol productive. In many other attributes, however, the ecosystems of the Seven are unusually suppressed, immature and depauperate.

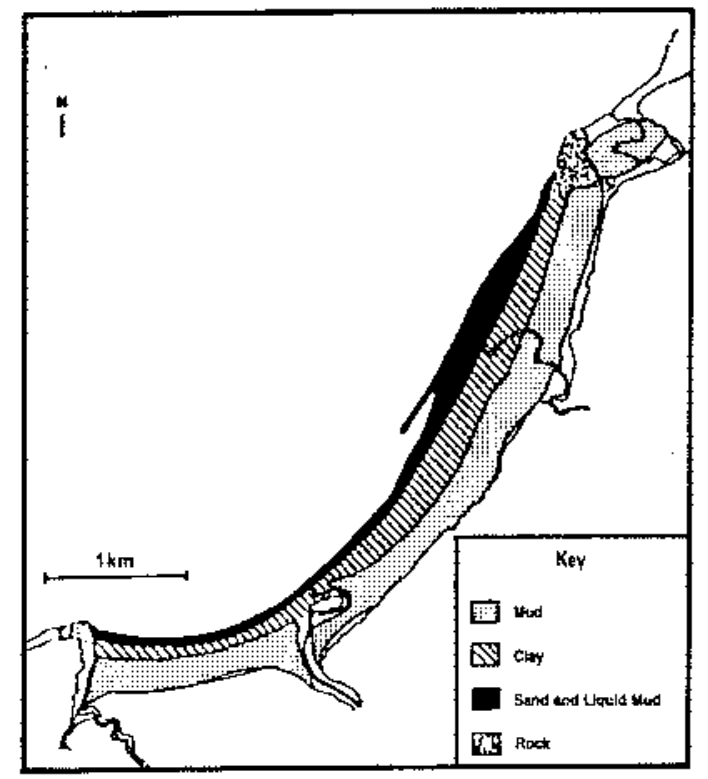

a) Surface substrates at Clevedon, November +979

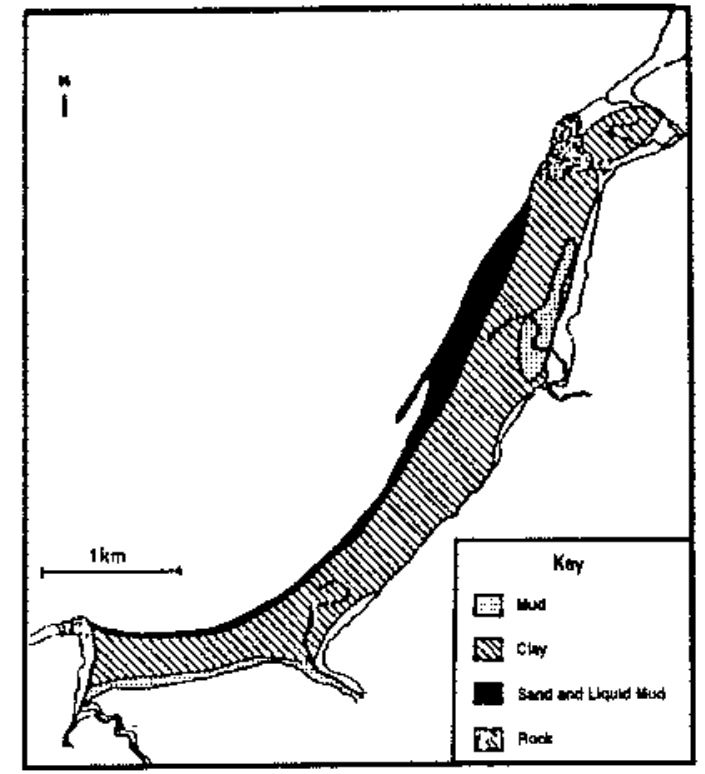

b) Surface substrates at Clevedon, December 15 th 1979

2. Large scale erosion of tidal flat substrate at Cleveden in the Severn Estuary due to gales. The material marked as "mud" is the only sediment providing a host for burrowing invertebrates [6]. 


\subsection{Intertidal zone}

The virtual absence of a shelly fatuna, is revealed by forsil deposits, persist. today $(10,11,12,13,14,15$ ! In a few random areals and at times, massive scalc spat recruitment into the thin unconsolidated sediment veneer can lead to colonisation by very large numbers of a few common and hardy species, Nereis diversicolors, Hydrobia atvae elc... Sich colonies may in the immediate term give the impression of high biological productivity. However, these remain immature pioneering communities unable to recruit other species and for the most part get wined out by any one of the severat step-changes to the intertidal sedimentery regime itemised above. The exposed overconsolidated Holocene clays and peats, in contrast, are almose always barren, other than for a summer micro-algal bloom and occasional immature Hyarobia ulvae on the surface. Intertidal sands also provide no usefur realistic trabitat, but in this case due to their extreme instability.

A direct consequence of the general impoverishment of the regime, coupled with the tuiversally small physical size of the imnature invertebrate shorebird foodstuffs which do gain a temporary foothold, is that the carrying capacity for these higher spectes in the Severn is lower than virtually anywhere in the LK, even then less productive sandy shore sediments elsewhere in the $\mathrm{UK}$ (tabl. 1) and, furthermore, the bird fauma are doninated numerically by a small species, the dunin, which can sustain itself on small prey specics. Those few relatively elcvated areas in respect of carrying capacity $(f i g .3 \%$, are explained in the one case by existence of un interidat shelduck roost and in the others by erhanced levels of shore bird prey species in the immediate vicinity of scwage outtalls.

An attempt has beck made to quantify the natural variability of intertidal prey species faund in the stme genem geographical area as the Severn Estuary. Variability in a number of manirestations was tested (fig. 4) [15, ]6t. Witholi exception, Severn faunas fell outside the natural envelope of variability which characterises adjacent shores. This separateness was provisionally attributed not so much to the exceptional tidal range at the site and its size but more to the stressfut nature of its physical regime imposed through the aspects of the sedimentary reme outlined above. The question driving this latter sturiy was whether and in whet respet the interti. dal invertebrate fatral community wotd atter due to construction of a Cardifl-Weston Barrage.

Table 1. - Bird Burdens - UK Estuaries

\begin{tabular}{|c|c|c|c|c|}
\hline Location & $\begin{array}{c}\text { Area }\left(\mathrm{km}^{2}\right) \\
\text { of intertidal } \\
\text { zone }\end{array}$ & $\begin{array}{c}\text { Wader months } \\
\text { Nov-Mar }\end{array}$ & $\begin{array}{c}\text { Winter wader } \\
\text { mths } / \mathrm{km}^{2}\end{array}$ & $\begin{array}{l}\text { Mudshore } \\
\text { Substrate }\end{array}$ \\
\hline $\begin{array}{l}\text { Moray Firth \{lnner\} } \\
\text { Forth } \\
\text { Wash } \\
\text { Medway } \\
\text { Southampton Water } \\
\text { Severn } \\
\text { Dee } \\
\text { Mersey } \\
\text { Ribble } \\
\text { Morecambe Bay } \\
\text { Solway }\end{array}$ & $\begin{array}{c}23.9 \\
49.8 \\
270 \\
19.9 \\
13.4 \\
196 \\
81 \\
45.4 \\
91 \\
303 \\
205\end{array}$ & $\begin{array}{r}28,922 \\
131,251 \\
744,981 \\
96,914 \\
43,397 \\
218,222 \\
280,788 \\
92,413 \\
209,117 \\
744,981 \\
252,363\end{array}$ & $\begin{array}{l}1,210 \\
2,636 \\
2,759 \\
4,870 \\
3,239 \\
1,114 \\
3,466 \\
2,036 \\
2,298 \\
2,759 \\
1,231\end{array}$ & $\begin{array}{l}\text { Sandy } \\
\text { Muddy \& Sandy } \\
\text { Sandy \& Muddy } \\
\text { Miuddy } \\
\text { Muddy } \\
\text { Muddy } \\
\text { Sandy } \\
\text { Muddy \& Sandy } \\
\text { Sandy } \\
\text { Sandy \& Muddy } \\
\text { Sandy }\end{array}$ \\
\hline
\end{tabular}

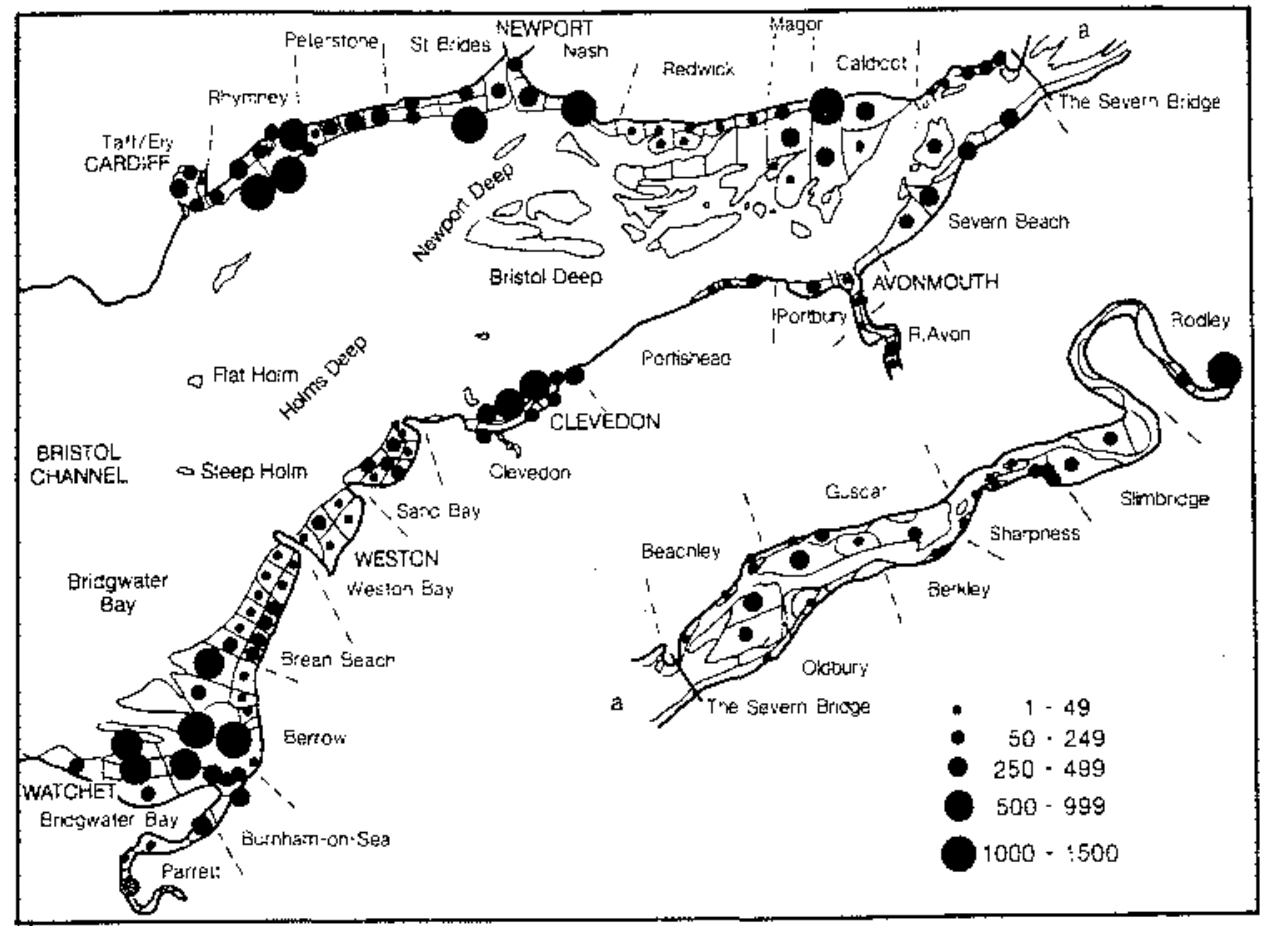

3. Average total number of waders and Shelduck present at fow tide on intertidal areas in the Severn during the $1987 / 88$ winter. Other than off Berrow, where nucleation is due to a Shelduck roost, the sites with elevated numbers are around sewer outfalls. (Data from BTO). 


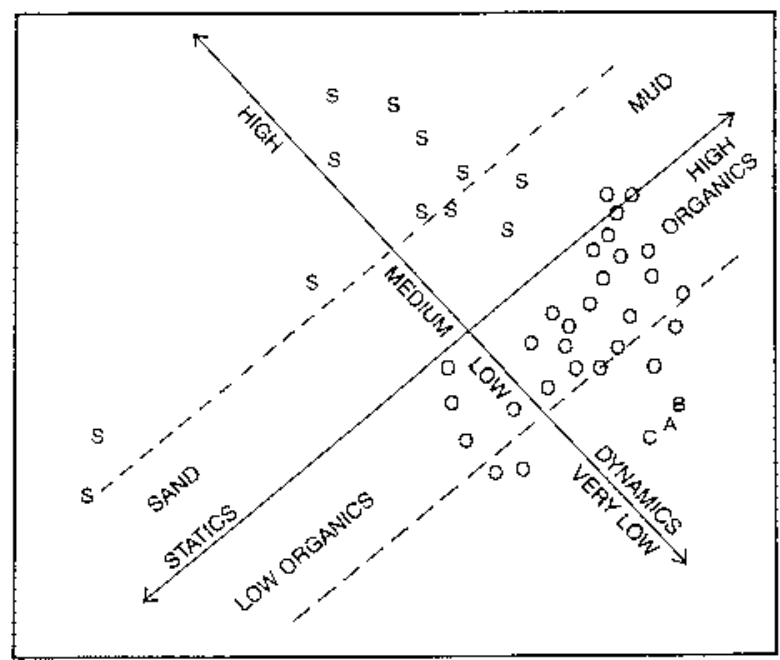

4. Multi-dimensional scaling ordinations for invertebrate abundance data from the Severn Estuary (S), other estuaries in $\mathrm{SW}$ Britain $(O)=$ Southampton Water, Poole Harbour, Exe, Plym \& Tamar Estuaries; and La Rance $(A, B \& C)$ showing distributions of stations relative to sediment static and dynamic factors. A plot of biomass versus the same sediment factors would look very similar. Constructing a Severn Barrage would alter the sediment statics and dynamics, shifting Severn invertebrate abundance and biomass into the region occupied by other estuaries and La Rance. [15].

\subsection{Subtidal zone}

Other than in a number of hard grounds where Sabellaria colonies protiferate, the darkness, jnstability, sediment load and regular deoxygenation of the nearbed zone renders it a difficult one for organisms to colonise. In addition to the general inmalurity of those fow individuals from pioneering species which are found, another notable feature of the fatsnal asscmblages is the complete absence of fither-feeding organistms. The latter are, of coutse, especially susceptible to gill-clogging from the ambient suspended sediment load. In those infrequent situations when subtidal faunas are discovered, they are distinguished by these site-specific atuibutes, namely immature examples of a very narrow range of common detritus-feeding pioneerine species and lacking the filter-feeding component of a balanced community $[17,18 \overline{1}$.

\subsection{Water colunin}

It has been explained that recruitment into the Severn is large in scale and constant. Elsewhere one might anticipate a prolilic ecosystem. That this is not so is chicfly explained by the very high suspended sediment concentration and the semi-perpetual mixing which maintains it. This leads to inhibition in photosynthetic activity $[19,20,21,22,23,24\}$. In the Outer Bristol Channel Joint \& Pomroy [19] estimated an annual primary production of 164.9 grams of carbon $/ \mathrm{nz}^{2} /$ year as an indication of phytoplankton activity, which falls to $6.8 \mathrm{gCm}^{-2} \mathrm{yr}^{-2}$ in the Frner Bristol Channel and to \%ero in the turbid waters of the Severn. Frequently the photosynthetic depth is as little as a few centimetres whilst mixing is sufficiently intense that photosynthetic micro-organisms only experience exposure to sunlight very occasionally and for too short a time period to become established. The large

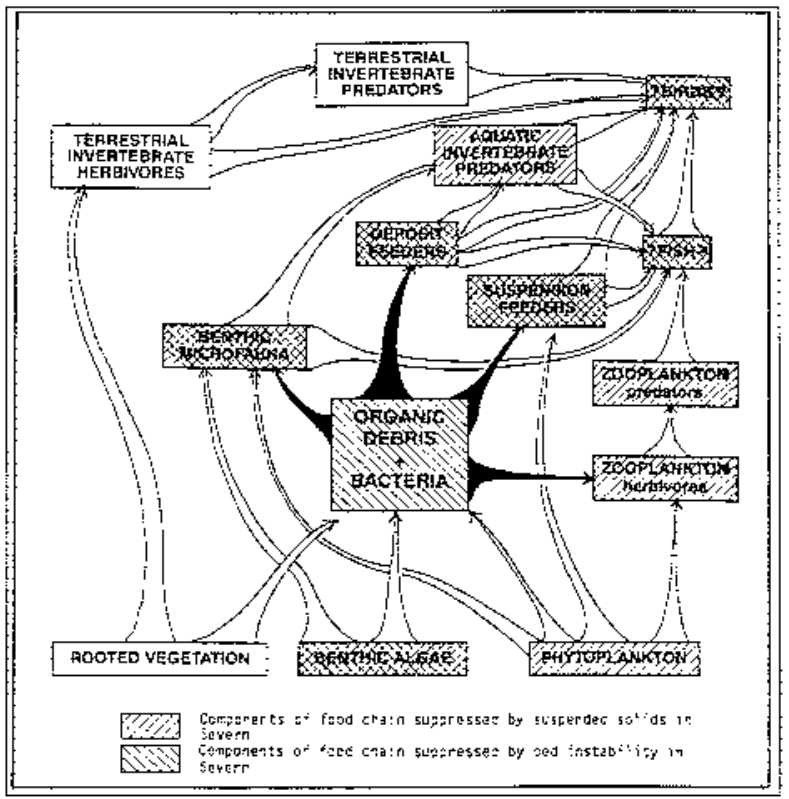

5. Diagram showing food chain of the main ecological groups of estuarine animals. Arrows go from food to consumer. Aspects of the fine sediment regime in the Severn impinge on the ecosystem as indicated.

scale inhibition of phytoplankton growth implies that the dependent higher foodchain is also inhibited (ftg. 5 ; [25].

Higher species such as vertebrate fish appeis to cope with this attribute of the environment but evidently adopt specific strategies to cope with the regular fortrightly dissolved oxyget sags of the main estuary in the region of Avonmouth and above. Evidenty they are able to regulate their movement and remain down-estuary until the inclement conditions ameliorate. Such strategies are especially important for migratory species such as salmon which must penetrate the inner reaches of the main estuary and the tributary river estuaries in order to reach their spawning grounds.

That the Severn is well supplied with spat by the large scate recrutitment and that the suspended sediment population is a determining control is evident from impourded dock systems on either side of the estuary 125 ;. Estuary water, sespended sediment and spat are added to the dock during locking operations and to maintain dock water level. In the quiescent docks the sediment settles and mature colonies of filter feeders such as mussels, which never gain a toehold in the estuary, can develop.

It is arguably the case that the conservation value of the Severn is naturally and in some cases rapidly deteriorating. The intertidal zone is becoming narrower and stecper as well as increasingly sensitive to erosion. There is circumstantial evidence that the overall turbidity of the estuary has increalsed with time. Increased water turbidity, if it were real, would steadily degrade the already highly marginal subtidat bed habitats, as well as perpetuating the pholosynthetic and regular dissolved oxygen problems induced by the sediment load. Arising from this one might pose the guestion whether a tidal barrage, and the tegime changes it would intuce, is or is not an asset in conservation terms. To be able to consider this, one would need to know how the regine would change due to construction. 


\section{1 POST-BARRAGE SEDIMENTARY REGIME}

The Sevem Barage, as most recently contigured along the Catdiff-Weston line, would take about nine years to construct. The latest design is such that the sedimentary regime, other perhaps than the degree of local coast protection afforded, would remain invariant or nearly so until the time of closure. There would, conscquently, be no transitional phase. At closure the tidal range would shift from hyperlidal to macrotidal, mean low water mark would rise by about $3.0 \mathrm{~m}$ and the semi-lunar variation in tidal range witinin the basin woulc become negligible, as a by-product of maximising energy outpul. This hydrodynamic clange would induce major shifts in the sediment regime.

\subsection{Intertidal sedimentary regime}

Raising mean water level within the basin is estimated 10 lead to the loss of $62 \%$ of the intertidal area. The wave and current regine of the $38 \%$ remaining would also change. In the longer term the cross-sectional shape of tidal mudflats in a number of areas is likely to evolve from their present low and concave to a high and convex profile due to deposition. Where these revisions occur, salt marshes may re-cstablish or become stable at the top of the shore. The nature of the substrate will also chenge in a significant way. The unconsolidated sediment veneer providing the host for invertebrates will become more exiensive and more stable. Fortnightly fluid mud deposition will cease. The effect of tixing the tidal range may be important. especietly in view of the relatively prolonged stillstand at high tide. An croding notch may be created to offset the trend to deposition elsewhere in cerain intertidal profiles. The decrease in the efficiency of grain-size fractionation may result in more mixed substrates developing. At present the sands sre largely confrned to offshore banks.

Followint the rise in mean water level, the area of such exposed mid-channel deposits will reduce drastically. Offshore sand banks at present tend to aceumulate mud in the protectod megaripple troughs. In the somewhat more benign macrotidal regime, more uniform mixing of the sand with a minor mud fraction to create muddy sand substrates is likcly in some arcas.

Outside the basin in Bridgwater Bay the tidal range will change little and the tidal flats will remain unchanged in their low and concave shape and eroding condition.

\subsection{Subtidal sedimentary regime}

At closure extensive near-bed fluid mud deposits would be induced, mainly in subtidal channel sites, as routinely oceurs at neap tides at present. Subseguenty, these would consolidate, initially increasing the arca of mud substrates compared to sand. Newport Deep is already muddy so no change would be detectable, but mud deposits are likcly to be emplaced in the Holms Deep and in Bristol Deep at least from Clevedon backing tp-estuary beyond Avonmouth into the inner estuary. The tributary river estuaries will also expcrience such once-off large scale deposition. In the revised regime, bed stability will increase srcatly and ncap tide fluid muds and their neap to spring entrainment and dissolved oxygen sag witl to all intents and purposes disappear.

The short, sharp flood tide is likely to mean that upestuary sand transport and fractionation will continue, possibly at a lower rate. The fact that the barrage will physically sever the link between the inner Bristol Channel, the long term source of sand, and the Severn will not lead to undue sand starvation in the enclosed basin adjacent to the barrage on grounds that this source is already virually exhausted.

The extreme separation of mud and sand populations which characterises the present estuary will change, with sediment types being more evenly spread.

Seaward of the barrage the subtidal sedimentary regime in Bridgwater Baly will experience little change, although dividing the embinment off trom the Severn and reducing the erosion of its extensive tidal flats, coupled with probable loss of suspended material entrained by maintenance dredging operations at the ports, will reduce the siltation rate around the oftshore periphery of the mud patch.

\subsection{Water column}

Arising from the reduction in current strength, the total suspended load of the estuary will diminish from in excess of 30 million tomes on springs to more modest values possibly close to 5 million tonnes. Moreover, other than in Bridgwater Bay, the fortnightly cycling of sediment between the water surface and the bed, leading to regular fluid mud for mation, will cease. Mcan water colunn lurbidities will lie in the normal range for macrotidal estuarics and can already be predicted from a targe existing data base. The basin-wide reduction and termination of fortrightly cycling, with its accompanying short term dissolved oxygen sag. will atl have an impact on the estuarine water quality.

Outside the basin spring/neap oscillations of the same magnitude as today would continue. In Bridgwater Bay, which is the only area of signiticant unconsolidated scdiment seaward of the barrage, the turbidity maty be expected to reduce compared to today both on account of the prolonged high tide stillstand and partial physical scparation from the sediment sources in the Severn caused by the burage.

\section{$V \square$ POST-BARRAGE BIOLOGICAL RESPONSE}

\subsection{Intertidal zone}

In Bridgwater Bay the steady and progressive intertidal deterioration is likely to continue much as it is loday and the flora and fauna are unlikely to alter. Within the enclosed basin a marked change can be anticipaled. A more normal macrotidal invertebrate faunal community will develop chatacterised by a wider range of species, animals growing to full maturity and the area becoming suited to the wide range of filter feeders present in ecosystems elsewhere. These more stable and prolific communitics can be expected to inerease further the physical mixing of scdiment types, as a wider spectum of sedinent grades will be co-deposited. Not just mud or sand faunas, but sandy mud and muddy sand communities are inevitable.

Although the intertidal area will reducc by $62 \%$, bird catrying capacity in the remaining $38 \%$ of the area will at least double or treble [26], more than accounting for any birds displaced by simple area loss calculations. The bird community, dependent as it presently is on the small size of prey species, will no longer be limited in this way. The dominance of dunlin, Caldris alpina, in the shorebird fauna will decline in relative terms due to larger foodstuifs suited to larger birds being avatlable.

Mid-estuary sites, currently unused by shorebirds, are likely 10 experience an increase in carrying capacicy dise to a rise in stable sand and muddy sand invertebrate communttics. Greater biological productivity can be expected to leat to an increase in vertebrate fish numbers and variety. 


\subsection{Subtidal zone}

The generally stunted and suppressed fatuns of the subtidal zone within the basin will change due to the increase in stability and absence of fluid mud veneers. Mud and sandy mud funal communities can be expected to expand the most. Very targe scale colonisation of currently inclement and barren substrates will lead to the formation by bioturbation of extensive muddy sand and sandy mud communities.

\subsection{Water colunn}

The very major decrease in turbidity, coupled with the reduced scale of semi- diurnal cycting, will greally increase jight penetration, leading to a large scale increase in pholosynthetic activity and releasing the entire food chain from the perpetual inhibition which characterises the area. Estuarine waters will not quite resenble impounded dock weters but will move towardis this condition. Hereased micro-organism activity may have an impact on nutrients introduced from the drainage basin which have not been lixed in the waler column in the inner reaches heretotore. 'The large scale of barrage tidal flushing will not induce any tendency for plankton blooming to occur.

\section{VI : CONCLLSION}

Arising from the extreme degree of conirol imposed upon the present ecosystem by the physical regime in general and a variety of attributes of the ifine sediment in particular, constructing a tidal power barretge along the Cardiff-Weston line in the Severn would inevitably give rise to all-pervasive modification to the ecosystems of the shore and bed and of the water column.

Society would need to judge whether luture changes the estuary maty experience are desirable or otherwise. It is recogrised that, irrespective of barage construction, when seendary sewage treatment replaces the present primary treatment that shorebird carying capacity will experience an inevitable and major decline. In such circumstances, is improving scwage treatment with its implication for shorebird stutainability an environmental improvement? Furthermore, our understanding of the system is sufficiently advanced that we recognise that the ecosystems of the Severn are naturally degrading in the longer term. A tidal power barrage is one route towards maintaining or entancing the mumber, variety and stability of floras and feurnas. Building such a barrate would lead to shorebird numbers increasing in spite of the decrease in area. For some reason this aspect of the entire econysten is subject to a disproportionate level of public incerest in the UK. Consequenty, we need to consider whether barrage construction is environmentally beneficial or otherwise.

In its 30 th anniverstry year, the tidal power butige at La Rance provides ever morc important lessons about construction, operation and optimisation of such systems and the necessity for rigrorous environmental monitoring. It has less to tcach us about the effects of construction in an estuary so dominated by its line graned sediment as the Severn.

Whether a tidal power batrage is ever built or not, the review above reveals that the Severn is an example of an cstuary crying out for sensible management.

\section{REFERENCES}

[1] HAwir.ton D., 1978. - Tine kigin energy satnd and mud regitre of the Severe Esluary, SW Briteir, Ir: Cotston Pupers No 30. Tida: Power \& Estuary Mar:zererent. RT Severn, D Dinelcy \& Le Halwker (Eds). Scientechnicz, pp. 162-172.
[2] KJRisY R., 199:. - D:stingtishing features of layered mists

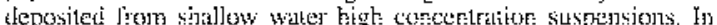
The uticro-structurc of fitc-grained seciments: frorr. mud to shalc. Springe: Veriag: Bertin, po. 167-:73.

[3t K:REY R. :989. - Devedopnent of a methodology to predict changes to tidal flat sindpes itrising [rom Lidal powe: schemes. Reporl to Scvest Tiditl Power G:oup, 92 pp.

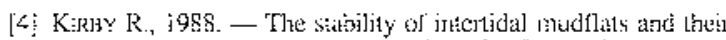
relistiosship :o :org te:m sotrces anc sinks for tine sediment : witi particular reference to ib Sesern Estatry and Bristol Clatane:

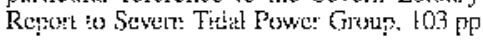

[5] Kerвy R. i986. - Suspended fine colhesive sidjument in the Severt Estualy and anc Inecr B:jitol Channel, LK. Report to ETSU No. ETSL'-STP-4042, $243 \mathrm{pp}$

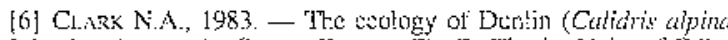
L.) wintering on the Scven Estuary. P|. D. Thesis, Liniv of Ldinburg. $358 \mathrm{pp}$.

71 Wor M.S. \& Wis: J.K., 199; - Spatia: anci lenpomat variaLоль in UK. I: : Estuaries \& Conses. M. Elliol: \& J.P. Ducrocoy (Edsi. Alson \& Alson, fredenstrarg, pp. 25-30

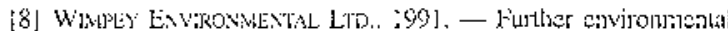
and energy capture studies. Report Nu. ETSL-THD-4099, 50 pp

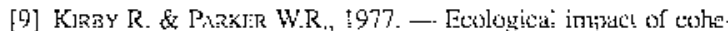
sive sedimert suspensions. Coutuibution to Scriviat 6 "Eco:ogica aspects of dudging". Seventant'? LAHR Conference, Baden-Baden pp. $854-857$.

[10] BOYDEN C.R. \& LJTruE C., 1973. - Faunal distribulions in

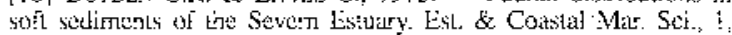
pp. $203-223$

111 WorkaLL D.H., 1981. - The reedine bebasiour of Dunlin (Catidhis atpira L.). Pl. D. Thes:s, University of Wales, Cardiff, (Caistims.

[12] Morristy D.J. \& Ste S.M. :988. - Ecology of the stbestuaries of èe River Severtr. 2 Vo:s. Dept. of Energy' Report : Vo. ISSTL-TID-4057.

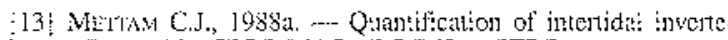
bralcs. Repori. No. SBDP-MACN/3.7(I)d2 to STPC.

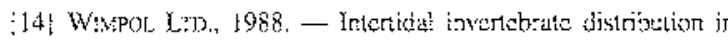
the Severt Fildaty. A baseline sLidy, STPG, SBDP/MACA/3.7(D)d,

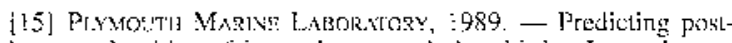

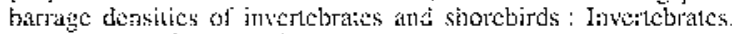
Repolt No. LTSL: TID 4061, 14] pp.

161 WARW:CK R.M., GOSS-C.STMRD J.D., K:REY R.: GEORGE C.L. Pols: N.D \& Round: A. A 1991 - Static and dynazic environ-

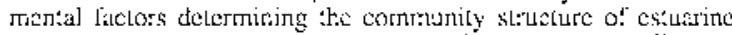

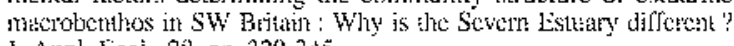
J. Appl. Eco:.., 28. pp. 329-345

:17] Htscock K. \& Cax:romgr: D., :980. - Seven Tidal Power Environmental inplicaljons in ararstore sub!jtora? ancus. 1'icid Studics Cotnci:. 4l pos.

:181 MerThM C.J., :9885. - Distribution of sublidal bcribos alssociated witi scdiments. Report N, SBDP/MACA/3.7(1)d3.14 10 STPG.

19] JoNi I.R. \& Poxtroy A.J., 1981. - Prin:ary produclion it a turbid estuary. Es. \& Coastal. Ma:. Sci., 13. py. 303-316.

|20| Jolx' 1.R. \& POMReY A.J., \$982. - Aspects of :ricrobial hetcrotrophic prodaction in al highly lu:bid estuary. 3. Fxp. Mar. Bits. Ecol. 58 , ז?. 33-46.

[21] Jolvt I.R., 1984. - The microbial ceology of the Bristol Cuancl. Ma: Poll. But: i5, (2), pl. 62.66.

[22) Mor]राs A.W. 1984. ... The chenistry of the Sewern Estuaty and the Bristo: Ctannel. Mas: Pold. Butt., 15: (2), pp. 57-61.

[23: WubinMs R., 1984. - Zooptankton in the Bristol Channe] \& Severn Fstuary. Mar, Polt. Bull., 15, (2), pp. 66-70.

[24] Owats M, 1984. - Severn Exturey. Ar appraisal of wate: cquality. Mat: Pol\}. But:, i5 (2), pp. 41-47.

[25: КнзнY R., 19896. - Thr ccologrical implications of postib]c changes in the secimentologica! tegime calsed by the proposed Severn Batrage. Repon io Sevem Tidal Power Group. 72 pp.

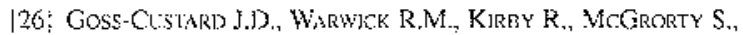

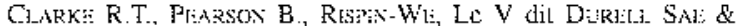
Rost: R.J., 1991. ... Towatds prcdicting wacing bird densitics from precticted prey densities in a frost-barrage Severn Estuary. J. Appl. Ecot., 28, pp, $100 \%-1026$ 